\title{
Effect of Sclerotium Density and Irrigation on Disease Incidence and on Efficacy of Coniothyrium minitans in Suppressing Lettuce Drop Caused by Sclerotinia sclerotiorum
}

P. Chitrampalam, Division of Plant Pathology and Microbiology, Department of Plant Sciences, University of Arizona, Tucson 85721; T. A. Turini, University of California Cooperative Extension, Fresno County 93702; M. E. Matheron and B. M. Pryor, Division of Plant Pathology and Microbiology, Department of Plant Sciences, University of Arizona, Tucson

\begin{abstract}
Chitrampalam, P., Turini, T. A., Matheron, M. E., and Pryor, B. M. 2010. Effect of sclerotium density and irrigation on disease incidence and on efficacy of Coniothyrium minitans in suppressing lettuce drop caused by Sclerotinia sclerotiorum. Plant Dis. 94:1118-1124.

Field experiments were conducted over 2 years in Yuma, AZ, and Holtville, CA, to establish the relationship between soil sclerotium density of Sclerotinia sclerotiorum and the incidence of lettuce drop on different lettuce (Lactuca sativa) types under different irrigation systems, and to determine the efficacy of the biocontrol agent Coniothyrium minitans (Contans) against S. sclerotiorum on crisphead lettuce at varied sclerotium densities under different irrigation systems. There was no significant interaction of irrigation (overhead sprinkler versus furrow) with either sclerotium density or with biocontrol treatment. Lettuce drop incidence was lowest in romaine lettuce compared with crisphead or leaf lettuce at all soil sclerotium densities. There was a significant positive correlation between the sclerotial density and the percent disease incidence. Disease incidence in plots infested with 2 sclerotia $/ \mathrm{m}^{2}$ of bed was not significantly higher than in control plots regardless of lettuce type. However, plots infested with 40 or $100 \mathrm{sclerotia} / \mathrm{m}^{2}$ of bed revealed a significantly higher disease incidence over the control in all lettuce types. A single application of Contans at planting significantly reduced the incidence of lettuce drop in all lettuce types even under high disease pressure. There were no significant differences between recommended $(2.2 \mathrm{~kg} / \mathrm{ha})$ and high $(4.4 \mathrm{~kg} / \mathrm{ha})$ application rates of Contans or between one or two applications of the product.
\end{abstract}

Lettuce (Lactuca sativa L.) is one of the most economically important vegetable crops grown in California and Arizona, and 95\% of U.S. lettuce production occurs within these two states. Between these states, production occurs in three distinct regions depending on the season: spring and summer production is concentrated in the Salinas Valley and coastal California; fall and spring production occurs in the San Joaquin Valley, CA; and winter production is concentrated in the desert valleys of Yuma County, AZ, and Imperial County, CA $(7,20,41)$. However, in all production areas, lettuce drop is one of the most common and destructive diseases $(19,40,52)$ and crop losses due to lettuce drop may vary from $1 \%$ to nearly $75 \%$ (45). In some cases, entire fields may be lost (47).

Lettuce drop is caused by Sclerotinia sclerotiorum (Lib.) de Bary and S. minor

Corresponding author: B. M. Pryor

E-mail: bmpryor@u.arizona.edu

Current address of P. Chitrampalam: Department of Plant Pathology, University of California, Davis 95616.

Accepted for publication 2 June 2010.

doi:10.1094/PDIS-94-9-1118

(c) 2010 The American Phytopathological Society
Jagger. Both fungi are present in the lettuce-growing areas of Arizona and California. However, the prevalence of these fungi in the different production region is distinct. $S$. minor is the predominant species in cooler coastal California whereas $S$. sclerotiorum is the predominant species in desert production areas of Yuma and Imperial Counties (48). Both fungi produce sclerotia as survival propagules, and $S$. minor mainly infects lettuce crops through direct germination of sclerotia. However, $S$. sclerotiorum infects either through direct germination of sclerotia or through ascospores formed from apothecia produced by carpogenic germination of sclerotia. The formation of apothecia and subsequent ascospore production depends on soil temperature and moisture $(3,16,48,51)$, and conditions conducive for this are infrequently encountered in desert production areas (37); therefore, the main cause of lettuce drop in the southwest deserts is through direct germination of sclerotia of S. sclerotiorum.

Previous studies on sclerotium populations of $S$. sclerotiorum in winter lettuceproduction field of Arizona and California revealed that the sclerotium population in commercial fields may be as high as 3 sclerotia per $100 \mathrm{~g}$ of soil (11). The high sclerotia population may be due to the intensive lettuce-cropping systems that occur in the winter in the southwest deserts. However, that study did not assess the potential impact of inoculum on subsequent lettuce production. Thus, the study on the relationship between sclerotium density and disease incidence in desert winter production is lacking but is critical for the future development of more effective management strategies.

Commercial lettuce production is primarily focused on three general lettuce types: romaine, crisphead (iceberg), and leaf, with many cultivars developed for each type. There are presently no commercially acceptable lettuce cultivars regardless of lettuce type with known resistance to either Sclerotinia spp., although romaine types appear less susceptible to lettuce drop due to their upright growth habit $(18,48)$. Efforts are underway to move potential sources of resistance from wild lettuce species into commercial lines but it will be many years before these are available to growers (22). Crop rotation offers some promise for disease management because rotation from lettuce to broccoli, a nonhost, resulted in a significant reduction in number of sclerotia of $S$. minor and the incidence of lettuce drop in a previous study (21). However, the effect of broccoli rotation on $S$. sclerotiorum has not been evaluated. Furthermore, lettuce production in Arizona and California is location specific and very intensive, and the economics of taking land out of lettuce production for any length of time are often not justifiable. Moreover, both Sclerotinia spp. have broad host range and extended survival in soil in the absence of hosts. Thus, crop rotation is often not an acceptable management alternative $(16,48)$.

More commonly, management strategies for lettuce drop rely heavily on chemical applications. However, fungicides such as dicloran (Botran) and iprodione (Rovral) have provided only a modest level of control of lettuce drop in most situations $(10,34,37,48)$. Moreover, the ability of iprodione to control lettuce drop under intensive lettuce production can be short lived due to rapid degradation in soil or development of resistance in Sclerotinia spp. $(12,26,48)$. The fungicide Endura (boscalid) has been recently introduced to manage lettuce drop caused by both Sclerotinia spp.; however, results from one field study showed that Endura provided a 
significant level of control only against lettuce drop caused by $S$. minor (37).

Biological control strategies using either mycoparasitic fungi that specifically attack fungal hyphae or degrade sclerotia or bacteria that inhibit fungal growth have been evaluated for the management of Sclerotinia spp. in a number of crops $(4,14$, $24,25,28,30,33,38,39,43,44)$. The most notable of these are Trichoderma spp., Sporidesmium sclerotivorum, Coniothyrium minitans, and Bacillus subtilis $(2,8$, $9,13,15,17,23,27,36,50,55)$. However, previous work from a field study by Chitrampalam et al. (10) revealed that neither Trichoderma nor Bacillus spp. provided significant control over either Sclerotinia spp. in desert lettuce production. In contrast, two applications of $C$. minitans significantly reduced the incidence of lettuce drop caused by Sclerotinia sclerotiorum and significantly increased the yield in both Arizona and California trials (10). However, the level of control achieved with $C$. minitans in Arizona trials was modest, as opposed to nearcomplete control in California trials despite higher disease incidence in control plots.

In the previous study, it was hypothesized that the sprinkler irrigation used in California experiments might have increased the dispersal of $C$. minitans following application or maintained more even soil moisture over the course of the growing season, resulting in near-complete parasitism of $S$. sclerotiorum sclerotia compared with greater fluctuation in soil moisture under furrow irrigation and modest control of lettuce drop in the Arizona trials (10). Therefore, the specific objectives of this study were to (i) establish relationships between sclerotium density and incidence of lettuce drop under different irrigation methods for crisphead, romaine, and leaf lettuce in desert soil and climatic conditions; and (ii) determine the efficacy of $C$. minitans against lettuce drop caused by $S$. sclerotiorum at different sclerotium densities under different irrigation methods.

\section{MATERIALS AND METHODS}

Field experiments. Two sets of field experiments were conducted at the University of Arizona Yuma Agricultural Center, Yuma and at the University of California Desert Agricultural Research and Extension Center, Holtville in the 2004-05 and 2005-06 cropping seasons. Experiment sites were chosen where there was no lettuce cultivation and no occurrence of Sclerotinia disease in the previous 2 to 3 years. Both experiments were designed as a splitsplit plot design with three replicate blocks. Lettuce was planted on beds with $102 \mathrm{~cm}$ between bed centers and two rows of lettuce spaced $30 \mathrm{~cm}$ apart on each bed. Each treatment plot consisted of four adjacent beds, $10 \mathrm{~m}$ in length. Within each plot, only the center two beds were evaluated to fully separate the effect of each treatment. For both experiments, inoculum consisted of sclerotia of S. sclerotiorum produced in the laboratory according to methods described by Matheron and Porchas (37). Inoculum was broadcast across the top of each bed by hand immediately before planting and was lightly incorporated into the top centimeter of soil during seeding that immediately followed.

All other cultural practices standard for desert lettuce production in Arizona and California were applied for each trial, including preplant applications of the herbicide Kerb (a.i. = pronamide; Dow AgroSciences, Indianapolis, IN), preplant and supplemental fertilization, and manual thinning and weeding as needed. At plant maturity and harvest, the numbers of healthy, symptomless lettuce plants from the center two beds were recorded and the percentage of lettuce drop incidence was calculated based upon differences between treatment plots and uninfested, unsprayed control plots. In addition, 10 marketable, asymptomatic lettuce heads were collected randomly from each uninfested control plot to assess potential growth stimulation benefits from each treatment.

Experiment I: effect of sclerotium densities on lettuce drop incidence under sprinkler versus furrow irrigation. The trial was carried out to examine the potential of $S$. sclerotiorum to infect different lettuce types at varying sclerotium densities under different irrigation methods. Irrigation method (furrow and sprinkler), lettuce type (romaine, crisphead, and leaf), and sclerotium density $(0,2,10,40$, and $100 \mathrm{sclerotia} / \mathrm{m}^{2}$ of bed) were the main plot, subplot, and sub-subplot, respectively. Main plots were randomized in 12bed blocks with two fallow beds between each block. For sprinkler irrigation blocks, sprinkler lines ran along the outside beds, with spray guards preventing irrigation from crossing onto adjacent blocks. Irrigation tail water was collected at the end of each bed into a secondary ditch and discharged away from the experimental plot. Lettuce cvs. PIC 714, Winterhaven, and 2Star were used for romaine, crisphead, and leaf lettuce types, respectively.

Experiment II: effect of $C$. minitans on lettuce drop under sprinkler versus furrow irrigation. A trial was carried out to test the efficacy of $C$. minitans and $B$. subtilis against $S$. sclerotiorum at varying sclerotium densities under different irrigation methods. Crisphead (Winterhaven) lettuce was used as host. Irrigation method (furrow and sprinkler), sclerotium density $\left(0,20\right.$, and 200 sclerotia $/ \mathrm{m}^{2}$ of bed), and treatment were the main plot, subplot, and sub-subplot, respectively. Main plots were organized as described above. Treatments included one or two applications of $C$. minitans (Contans; application rate $=2.2$ or $4.4 \mathrm{~kg} / \mathrm{ha}$; Prophyta, Germany) or $B$. subtilis (Companion; application rate $=4.4$ liters/ha; Growth Products Ltd., White Plains, NY). Single applications were made immediately after seeding but before initial irrigation. In the two-application treatments, the biocontrol agents were also applied after thinning at approximately 4 weeks post seeding. A chemical treatment consisting of a single application of Rovral 4F (a.i = iprodione; application rate $1.1 \mathrm{~kg}$ a.i/ha; Bayer Crop Science, Research Triangle Park, NC) was included for comparison as a chemical standard frequently used in desert lettuce production. Combinations of Contans and Rovral were also evaluated. Uninfested control plots received no inoculum, and infested control plots received no treatments.

Statistical analysis. Factorial analysis of variance (ANOVA) was performed for factor A (irrigation), with factor B (lettuce type in experiment I or sclerotium density in experiment II) as split plot on factor A, and factor $\mathrm{C}$ (sclerotium density in experiment I or treatment in experiment II) as split plot on B to test the effect of each factor and their subsequent interaction on the disease incidence. If the factorial analysis showed that irrigation was not a significant source of variation, then the disease incidence data from both irrigation types were combined as additional replicates and the two-way ANOVA was performed to analyze the effect of lettuce types, inoculum densities, and their interactions on disease incidence. A $\chi^{2}$ test for homogeneity of variance for data from each year in each location was carried out to test whether the 2 years of data from the Yuma and Holtville experiments could be combined as single data sets. Linear regression was performed to test the relationship between the variation of sclerotial inoculum density and percent disease incidence for each lettuce type. All statistical analyses were conducted using the Sigmastat software package (Systat Software Inc., San Jose, CA).

\section{RESULTS}

Effect of sclerotium densities on lettuce drop incidence under sprinkler versus furrow irrigation. The $\chi^{2}$ test revealed significant differences $(P=$ $0.00001)$ between trials that varied by location and year in a four-way analysis; therefore, these four data sets could not be combined as one. A second test revealed significant differences between the 2 years of Arizona trials $(P=0.0304)$ and the 2 years of California trials $(P=0.00001)$; therefore, these trials also could not be combined. A third test revealed significant differences between the 2004-05 Arizona and California trials and, therefore, these trials could not be combined; however, there were no significant differences between the 2005-06 Arizona and California trials $(P=0.1949)$ and, thus, 
these were combined for statistical analysis (Table 1).

Because irrigation types were not a significant source of variation of disease incidence in all trials, the disease incidence data from these two irrigation types were combined as additional replicates for the analysis of the effect of sclerotial density, lettuce type, and their interaction. Linear regression analysis revealed that there was a positive correlation between the amount of sclerotial inoculum present at the time of planting and disease incidence at the time of harvest, and disease incidence was increased with increase of sclerotial inoculum (Fig. 1). In 2004-05 in Yuma, disease incidence in plots with romaine lettuce as a host, containing 2 and 10 sclerotia $/ \mathrm{m}^{2}$ of bed, was 5 and $10 \%$, respectively, which was not significantly different from that of the control plot containing no sclerotia (Fig. 1A). However, the incidence of lettuce drop from plots containing 40 and 100 sclerotia $/ \mathrm{m}^{2}$ was statistically different from that of the control and resulted in 15 and $30 \%$ incidence of disease, respectively. In plots with crisphead lettuce as a host, the incidence of lettuce drop from plots containing 10,40 , and 100 sclerotia $/ \mathrm{m}^{2}$ of bed was 19,40 , and $61 \%$, respectively, which was statistically different from that of uninfested control plots (Fig. 1A). In plots with leaf lettuce as a host, the incidence of lettuce drop in plots containing 10,40, and 100 sclerotia $/ \mathrm{m}^{2}$ of bed was 35,56 , and $71 \%$, respectively, which was statistically different from that of the uninfested control plots (Fig. 1A).

Results were similar for experiments conducted in Holtville, CA in 2004-05. In plots with romaine lettuce as host, only the plots with 100 sclerotia $/ \mathrm{m}^{2}$ of bed (19\%) resulted in a significantly higher incidence of disease than the uninfested control $(0 \%)$ (Fig. 1B). In plots with crisphead lettuce as a host, only the disease incidence from plots containing 40 and 100 sclerotia $/ \mathrm{m}^{2}$ of bed (31 and $55 \%$, respectively) was significantly different from that of the control (Fig. 1B). In plots with leaf lettuce as host, the disease incidence in plots with 10,40 , and $100 \mathrm{sclerotia} / \mathrm{m}^{2}$ of bed was 25,69 , and $69 \%$, respectively, which was significantly higher from that of the uninfested control (Fig. 1B)

In the combined 2005-06 Arizona and California trials, disease incidence in plots with romaine as the host with 10,40 , and $100 \mathrm{sclerotia} / \mathrm{m}^{2}$ of bed was 10,17 , and $25 \%$, respectively, which was significantly higher than that of the uninfested control and the plot with 2 sclerotia $/ \mathrm{m}^{2}$ of bed $(6 \%)$ (Fig. 1C). In plots with crisphead lettuce as a host, only the plot containing $100 \mathrm{sclerotia} / \mathrm{m}^{2}$ of bed yielded an incidence of disease (18\%) significantly higher than that of the uninfested control (Fig. 1C). In the experiment with leaf lettuce as host, the disease incidence from plots containing 10,40 , and 100 sclerotia/ $\mathrm{m}^{2}$ was 9,19 , and $28 \%$, respectively, which was significantly different from that of the uninfested control (Fig. 1C).

Effect of $C$. minitans on lettuce drop under sprinkler versus furrow irrigation. As in experiment I, the $\chi^{2}$ test revealed significant differences $(P=$ 0.00001 ) between trials that varied by location and year in a four-way analysis; therefore, the four data sets could not be combined as one. A second test revealed significant differences between the 2 years of Arizona trials $(P=0.0017)$ and the 2 years of California trials $(P=0.0444)$ and, thus, these trials could not be combined. A third test revealed significant differences between Arizona trials and California trials $(P=0.00001)$ in 2004-05 and, therefore, these trials could not be combined; however, there were no significant differences between these two locations in 2005-06 ( $P$ $=0.8619$ ) and, thus, they were combined as additional replicates in statistical analysis (Table 2).

As in experiment $\mathrm{I}$, in all trials, there was no significant difference between irrigation types or significant interaction with the other variables (Table 2). Thus, data from different irrigation types were combined as additional replicates and reanalyzed as single data sets to better assess the effects of inoculum density and treatment on the incidence of disease (Table 3 ). In 2004-05 in Yuma, the incidence of let-

Table 1. Factorial analysis of variance for the effect of sclerotium density on disease incidence in three distinct lettuce types under different irrigation types

\begin{tabular}{|c|c|c|c|c|}
\hline \multirow[b]{3}{*}{ Sources } & \multirow[b]{3}{*}{ df $\mathbf{f}^{\mathbf{y}}$} & \multicolumn{3}{|c|}{$P$ value $^{\mathrm{x}}$} \\
\hline & & \multicolumn{2}{|c|}{ 2004-05 } & \multirow{2}{*}{$\begin{array}{c}\text { 2005-06 } \\
\text { Both }^{\mathrm{z}}\end{array}$} \\
\hline & & Arizona & California & \\
\hline Plot (irrigation) & 1 & 0.07880 & 0.3364 & 0.0639 \\
\hline Subplot (lettuce type) & 2 & 0.00001 & 0.00001 & 0.0030 \\
\hline Irrigation $\times$ lettuce type & 2 & 0.3840 & 0.0641 & - \\
\hline Sub-subplot (sclerotium density) & 4 & 0.00001 & 0.00001 & 0.00001 \\
\hline Irrigation $\times$ sclerotium density & 4 & - & 0.4117 & - \\
\hline Lettuce type $\times$ sclerotium density & 8 & 0.00001 & 0.00001 & 0.0689 \\
\hline Irrigation $\times$ lettuce type $\times$ sclerotium density & 8 & - & - & - \\
\hline
\end{tabular}

${ }^{x}$ Where $F$ value is less than $1(-)$, there is no $P$ value.

y Degree of freedom.

z Arizona and California experiments were combined as additional replicates in 2005-06.

tuce drop induced by $S$. sclerotiorum in infested control plots (no treatment) containing 20 and 200 sclerotia/ $\mathrm{m}^{2}$ of bed was 33 and $82 \%$, respectively (Table 3 ). In treatment plots containing $20 \mathrm{sclerotia} / \mathrm{m}^{2}$ of bed, combined treatment of a single application of the high rate of Contans with Rovral treatment resulted in the lowest incidence of disease (5\%). The incidence of disease in plots containing either one or two applications of the recommended rate of Contans was 12 and $11 \%$, respectively, and was not significantly different from that in plots treated with either two application of the high rate of Contans alone $(8 \%)$ or treated in combination with both a high rate of Contans and a
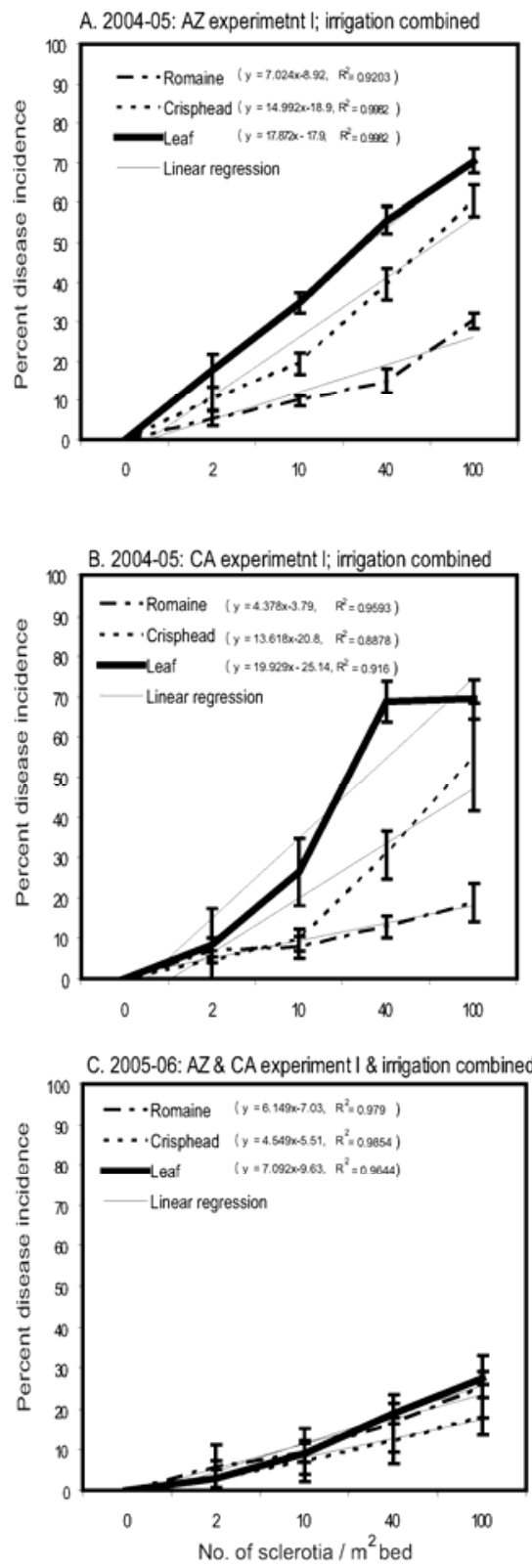

Fig. 1. Relationship between sclerotium density of Sclerotinia sclerotiorum and the incidence of lettuce drop for three different lettuce types: crisphead, leaf, and romaine. Bars indicate standard error of mean for three replicate plots per treatment. 
Rovral treatment (6\%). The incidence of disease from Rovral-treated plots was $16 \%$ and was also significantly lower than that of control plots. In treatment plots with high inoculum levels $\left(200 \mathrm{sclerotia} / \mathrm{m}^{2}\right.$ of bed), the incidence of disease in plots treated with either one or two applications of Contans at the recommended rate (16 and $17 \%$, respectively), one or two applications of Contans at the high rate (14 and $15 \%$, respectively), or low or high rates in combination with Rovral (16 and 8\%, that of control plots $(83 \%)$ or plots treated with Companion or Rovral alone (82 and $53 \%$, respectively). One or two applications of Rovral resulted in a significantly lower incidence of disease (53 and 50\%, respectively) than that of control plots (Table 3).

Results from experiments in Holtville, CA, in 2004-05 were similar to the results from Yuma experiments. The percent lettuce drop incidence from infested plots containing 20 and 200 sclerotia $/ \mathrm{m}^{2}$ of bed was 16 and $56 \%$, respectively (Table 3 ). In treatments with low levels of disease inoculum ( $20 \mathrm{sclerotia} / \mathrm{m}^{2}$ of bed), only the incidence of disease from plots containing either a single application of the recomrespectively) was significantly lower from

mended rate of Contans $(7 \%)$ or single or double applications of a high rate of Contans (4 and 4\%, respectively) or combined with the fungicide Rovral ( 7 and $2 \%$, respectively) was significantly lower than that of control plots. In treatments with a high level of inoculum (200 sclerotia/ $\mathrm{m}^{2}$ of bed), again, the plots treated with a single or double application of any rate of Contans sprayed alone or with Rovral resulted in significantly lower incidence of disease than either control plots or the Rovral plots. The incidence of disease from the Rovral plots was also significantly lower than that of control plots (Table 3).

In the combined 2005-06 Arizona and California trial, the disease incidence in plots with a low and high level of sclerotial inoculum was 16 and 39\%, respectively (Table 3). In plots with a low level of inoculum, only the treatments containing both Contans and Rovral resulted in an incidence of disease significantly lower than that of control. In treatments with a high level of inoculum, two applications of high rates of Contans combined with two applications of Rovral resulted in the lowest incidence in disease (15\%), which was significantly lower than that of control plots. The incidence of disease from treat-

Table 2. Factorial analysis of variance for the effect of different treatments on disease incidence under different irrigation types

\begin{tabular}{|c|c|c|c|c|}
\hline \multirow[b]{3}{*}{ Sources } & \multirow[b]{3}{*}{ df $\mathbf{y}^{\mathbf{y}}$} & \multicolumn{3}{|c|}{$P$ value $^{\mathrm{x}}$} \\
\hline & & \multicolumn{2}{|c|}{$2004-05$} & \multirow{2}{*}{$\frac{2005-06}{\text { Both }^{\mathrm{z}}}$} \\
\hline & & Arizona & California & \\
\hline Plot (irrigation) & 1 & 0.2832 & 0.4061 & 0.2965 \\
\hline Sub plot (sclerotium density) & 2 & 0.00001 & 0.00001 & 0.00001 \\
\hline Irrigation $\times$ sclerotium density & 2 & - & 0.2602 & 0.1664 \\
\hline Sub-subplot (treatments) & 9 & 0.00001 & 0.00001 & 0.00001 \\
\hline Irrigation $\times$ treatments & 9 & 0.3514 & - & - \\
\hline Sclerotium density $\times$ treatments & 18 & 0.00001 & 0.00001 & 0.00001 \\
\hline Irrigation $\times$ sclerotium density $\times$ treatments & 18 & 0.1992 & - & 0.1075 \\
\hline
\end{tabular}

x Where $F$ value is less than 1 (-), there is no $P$ value.

${ }^{y}$ Degree of freedom.

${ }^{\mathrm{z}}$ Arizona and California experiments were combined as additional replicates in 2005-06. ments containing one application of the high rate of Contans combined with one application of Rovral (17\%) was also significantly lower than that of the control (Table 3).

In analyzing head weight data, there were significant differences between irrigation types in both the Arizona and California experiments in 2004-05 $(P=0.009$ and 0.013 , respectively). However, there were no significant differences between the furrow or sprinkler irrigation at the two locations $(P=0.6234$ and 0.1502$)$. Thus, the data of furrow irrigation and the data of sprinkler irrigation from both locations were combined as additional replicates separately for each irrigation type and analyzed as single data sets to test the effect of irrigation, treatments, and their interaction on lettuce head weight. In both irrigation types, no significant increase in head weight was observed with any products (data not shown) but plots treated with Contans resulted in numerically higher head weight compared with uninfested, untreated control plots and plots treated with other products; however, the differences were not statistically significant (data not shown).

In the 2005-06 Arizona trials, there were no significant differences between irrigation methods; thus, data from different methods were combined as additional replicates and analyzed as a single data set to check the effect of treatments. There were no significant differences between treatments in increasing head weight (data not shown). However, plots treated with Contans resulted in numerically higher head weight compared with blank plots (uninoculated and untreated) and plots treated with other products. In the California experiments, there was a significant difference between irrigation types.. Again, there were no significant differences between the treatments in increasing the head weight in either irrigation type. However,

Table 3. Effect of different biocontrol products and Rovral on lettuce drop incidence in plots infested with Sclerotinia sclerotiorum in Yuma, AZ and Holtville, CA in 2004 to 2006

\begin{tabular}{|c|c|c|c|c|c|c|}
\hline \multirow[b]{4}{*}{ Treatments $^{\mathrm{z}}$} & \multicolumn{6}{|c|}{ Lettuce drop incidence $(\%)^{\mathrm{w}}$} \\
\hline & \multicolumn{4}{|c|}{ 2004-05 } & \multirow{2}{*}{\multicolumn{2}{|c|}{$\begin{array}{c}\text { 2005-06 } \\
\text { Both }^{\mathrm{y}}\end{array}$}} \\
\hline & \multicolumn{2}{|c|}{ Arizona $^{x}$} & \multicolumn{2}{|c|}{ California $^{\mathrm{x}}$} & & \\
\hline & Low & High & Low & High & Low & High \\
\hline 1. Untreated control & $32.7 \mathrm{~d}$ & $82.0 \mathrm{c}$ & $16.0 \mathrm{bc}$ & $56.1 \mathrm{c}$ & $15.5 \mathrm{c}$ & $38.8 \mathrm{c}$ \\
\hline 2. Contans, $2.2 \mathrm{~kg} / \mathrm{ha}$ at $P$ & $12.1 \mathrm{ab}$ & $15.5 \mathrm{a}$ & $7.1 \mathrm{a}$ & $6.9 \mathrm{a}$ & $11.0 \mathrm{abc}$ & $27.6 \mathrm{~b}$ \\
\hline 3. Contans, $2.2 \mathrm{~kg} / \mathrm{ha}$ at $\mathrm{P} \& \mathrm{~T}$ & $11.3 \mathrm{ab}$ & $17.4 \mathrm{a}$ & $7.3 \mathrm{ab}$ & $8.1 \mathrm{a}$ & $9.2 \mathrm{abc}$ & $25.7 \mathrm{~b}$ \\
\hline 4. Contans, $4.4 \mathrm{~kg} / \mathrm{ha}$ at $\mathrm{P}$ & $5.5 \mathrm{a}$ & $14.0 \mathrm{a}$ & $3.5 \mathrm{a}$ & $12.4 \mathrm{a}$ & $10.4 \mathrm{abc}$ & $24.7 \mathrm{ab}$ \\
\hline 5. Contans, $4.4 \mathrm{~kg} / \mathrm{ha}$ at $\mathrm{P} \& \mathrm{~T}$ & $7.7 \mathrm{a}$ & $14.7 \mathrm{a}$ & $4.3 \mathrm{a}$ & $7.5 \mathrm{a}$ & $9.5 \mathrm{abc}$ & $23.7 \mathrm{ab}$ \\
\hline 6. Companion & $26.7 \mathrm{~cd}$ & $81.7 \mathrm{c}$ & $22.0 \mathrm{c}$ & $54.3 \mathrm{c}$ & $14.6 \mathrm{bc}$ & $40.1 \mathrm{c}$ \\
\hline 7. Rovral at $\mathrm{T}$ & $16.5 \mathrm{~b}$ & $53.3 \mathrm{~b}$ & $10.5 \mathrm{ab}$ & $35.3 \mathrm{~b}$ & $8.9 \mathrm{abc}$ & $22.8 \mathrm{ab}$ \\
\hline 8. Rovral at T \& PT & $19.7 \mathrm{bc}$ & $50.2 \mathrm{~b}$ & $9.1 \mathrm{ab}$ & $24.5 \mathrm{~b}$ & $9.2 \mathrm{abc}$ & $19.4 \mathrm{ab}$ \\
\hline 9. Contans, $4.4 \mathrm{~kg} / \mathrm{ha}$ at $\mathrm{P}$ and Rovral at $\mathrm{T}$ & $5.2 \mathrm{a}$ & $16.1 \mathrm{a}$ & $6.9 \mathrm{a}$ & $9.2 \mathrm{a}$ & $5.2 \mathrm{a}$ & $17.2 \mathrm{ab}$ \\
\hline 10. Contans, $4.4 \mathrm{~kg} / \mathrm{ha}$ at $\mathrm{P} \& \mathrm{~T}$ and Rovral at $\mathrm{T} \& \mathrm{PT}$ & $5.6 \mathrm{a}$ & $8.5 \mathrm{a}$ & $2.4 \mathrm{a}$ & $8.4 \mathrm{a}$ & $6.8 \mathrm{ab}$ & $14.9 \mathrm{a}$ \\
\hline
\end{tabular}

${ }^{\mathrm{w}}$ Low and High $=20$ and 200 sclerotia $/ \mathrm{m}^{2}$ of bed, respectively. Within one column, means followed by the same letters are not significantly different according to Tukey's test $(P \leq 0.05)$.

${ }^{\mathrm{x}}$ Data from both furrow and sprinkler irrigation types are combined.

y Arizona and California data are combined.

${ }^{\mathrm{z}} \mathrm{P}=$ planting, $\mathrm{T}=$ thinning, and $\mathrm{PT}=$ post thinning. 
in furrow irrigation, plots containing Contans resulted in numerically higher head weight than blank plots and plots treated with other products. In sprinkler irrigation, Rovral treatment resulted in numerically higher head weight than that of blank plots and plots treated with other products but these differences were not statistically significant (data not shown).

\section{DISCUSSION}

This study documented the relative tolerance of major types of cultivated lettuce (romaine, crisphead, and leaf lettuce) to $S$. sclerotiorum and the effect of different irrigation systems currently employed in lettuce production in Arizona and California on the incidence of lettuce drop under different sclerotium inoculum levels. The cultivars tested are not reported to have tolerance to lettuce drop, nor are there commercially acceptable cultivars within each lettuce type with notable levels of tolerance to either Sclerotinia spp. Thus, the reported differences in disease incidence among the three lettuce cultivars selected in this study may represent general differences in tolerance to lettuce drop among types. Among the lettuce types tested, romaine lettuce was the most tolerant and crisphead and leaf lettuce were the most susceptible to $S$. sclerotiorum in both Yuma, AZ and Holtville, CA in 2004-05. The observed differences in the level of tolerance among lettuce types could possibly be due to the differences in the arrangement of leaves and formation of heads. Unlike crisphead and leafy lettuce types, romaine forms long, upright leaves with a firm rib down the center which could possibly limit the contact of leaves with soilborne sclerotial inoculum (46). In 2005-06, the incidence of lettuce drop recorded in crisphead and leaf lettuce was comparatively lower than that in 2004-05. An outbreak of gray mold (causal agent: Botrytis cinerea) in 2004-05 in Yuma and Imperial Valley potentially complicated lettuce drop assessment in that $B$. cinerea is a good secondary decay agent that readily colonizes plant crowns infected with Sclerotinia spp. and can obscure the infected area with extensive sporulation. Therefore, some Sclerotinia infections may have been missed and classified as gray mold.. The results from previous field surveys by $\mathrm{Wu}$ and Subbarao (53) revealed that the incidence of lettuce drop in leaf lettuce was significantly lower than that of romaine and crisphead, which is inconsistent with this study. However, the previous field surveys by $\mathrm{Wu}$ and Subbarao were carried out in lettuce production fields in the Salinas Valley, CA, where $S$. minor is the predominant species. In the present study, S. sclerotiorum was used as a pathogen and the relative level of resistance among different lettuce types to lettuce drop caused by $S$. sclerotiorum had not been previously determined (53). Because
S. sclerotiorum and $S$. minor differ in epidemiology, host range, and mode of infection $(1,53)$, it is likely that the two species may also differ in their ability to infect different lettuce types.

This study also confirmed that C. minitans is an effective biocontrol agent in suppressing lettuce drop caused by $S$. sclerotiorum. The Contans treatment outperformed the fungicide Rovral (iprodione) in most experiments. Although the results from the 2005-06 experiment with regard to the performance of $C$. minitans against $S$. sclerotiorum were consistent with the 2004-05 experiment, they differed with respect to the level of disease incidence and the level of disease suppression obtained with the different rates of Contans. In 2004-05 experiments at both locations, the level of disease suppression with Contans was nearly complete, one application of the recommended rate of Contans (2.2 $\mathrm{kg} / \mathrm{ha}$ ) at the time of planting was sufficient to completely suppress lettuce drop, and the level of disease suppression was significantly higher than that obtained with the commonly used fungicide, Rovral. In contrast, lettuce drop incidence and the level of control achieved with Contans were modest in the 2005-06 experiment. The reasons for the differences between the 2 years may again be related to the limited incidence of gray mold noted in the 2005-06 experiment. At both Yuma, AZ and Holtville, CA, in 2005-06, a low incidence of gray mold became apparent at the time of the trial harvest and complicated the assessment of the performance of Contans. Therefore, some Botrytis infections may have been misclassified as Sclerotinia, which resulted in less disease suppression with $C$. minitans. However, the overall results from this study on efficacy of Contans in suppressing lettuce drop were consistent with the results from our previous study (10).

A notable difference between this study and our previous study (10) was in the number of applications of Contans required to successfully suppress lettuce drop. Results from the previous study showed that one application of Contans immediately following planting did not significantly suppress lettuce drop but two applications of Contans, one following planting and one following thinning, did control lettuce drop significantly. In the current study, only one application at planting was sufficient. The reason for the differences may be related to one notable difference in experimental methods in these two studies. In the previous study, the pathogen inoculum was applied at thinning, as opposed to immediately before planting in this study. Because weather conditions in desert agroecosystems are not favorable for ascospore production, the infection is mainly through eruptive germination of sclerotia. Sclerotia usually initiate the infection at two growth phases in lettuce; the first phase is at the rosette stage, 3 to 4 weeks after seedling emergence, and second phase is near crop maturity. Thus, the application of Contans at the time of planting provides more opportunity for the slow-growing Coniothyrium fungus to find its host sclerotia and degrade them before the pathogen can attack lettuce seedlings. Because sclerotia are the main source of nutrients for $C$. minitans, application of Contans 1 month prior to application of pathogen inoculum (sclerotia) may result in loss of $C$. minitans population, which would result in reduced control of lettuce drop, as was observed in the previous study. Considering the effective impact of single applications of Contans on sclerotia populations and the many fields involved in lettuce production in Arizona and California every winter, additional benefits of Contans might be realized if growers applied Contans immediately following a lettuce crop so that degradation of any sclerotia that might have been produced would be initiated well in advance of the subsequent lettuce crops typically planted in the following season. The results on the overall efficacy of Contans on lettuce drop is consistent from this study with previous studies on the control of $S$. sclerotiorum using $C$. minitans in lettuce $(5,6,8,29,35)$ as well as on the biocontrol of Sclerotinia diseases of bean $(6,17,31,32)$.

Iprodione served as a standard fungicide in all experiments; the level of disease suppression achieved with iprodione was not dramatic and, in most trials, was significantly lower than that of biocontrol product Contans. This result was consistent with that of our previous study (10). Although, commercially, iprodione has been extensively used to control lettuce drop in both California and Arizona, and most studies revealed that it significantly improved lettuce drop control $(34,47)$, the field losses due to lettuce drop continue to be significant despite common fungicide use. Previous studies have found that suboptimal performance of iprodione in the field may be due to rapid degradation of the fungicide by soilborne microbes (37), which is exacerbated by high soil $\mathrm{pH}$ $(>6.5)$ common in desert production areas (54). Similarly, the Bacillus spp.-based biocontrol product, Companion, was not effective in suppressing lettuce drop at either location despite significant inhibition of S. sclerotiorum in dual-growth assays conducted in vitro (unpublished data). The reason for the failure of Companion in the field is unknown; however, it could possibly be related to the poor survivability of Bacillus spp. in the desert soil (42).

This study also revealed that the method of irrigation (sprinkler or furrow) did not have a significant effect on the ability of $S$. sclerotiorum to successfully cause disease in both Arizona and California trials. Re- 
sults from previous studies $(49,53)$ also revealed that lettuce drop incidence was lower in fields with either surface or subsurface drip irrigation than in fields with furrow or sprinkler irrigation system. Thus, the choice of sprinkler versus furrow irrigation does not appear to impact the management of lettuce drop in lettuce production fields. In addition, this study also revealed that there was no significant effect of irrigation on Contans performance on controlling lettuce drop because treatments applied under furrow irrigation performed similarly to those under sprinkler irrigation. However, a previous study by Bolton et al. (3) suggested that Contans is effectively splash dispersed and more effective under sprinkler irrigation in the greenhouse. Moreover, the results from our previous study (10) also suggested that $C$. minitans was more effective in controlling lettuce drop under sprinkler irrigation than furrow irrigation. This seemingly contradictory result between this study and the previous study could be due to differences in other experimental procedure methods followed for furrow or sprinkler irrigation rather than irrigation types alone. For example, in the previous study with furrow irrigation, Contans and pathogen inoculum were applied at the time of planting and thinning, respectively, as opposed to both being applied at the time of planting, as was the case with previous studies using sprinkler irrigation. The later placement of inoculum and treatment concomitantly facilitated a greater interaction between Sclerotinia spp. and C. minitans, resulting in corresponding greater disease suppression. In the current study, both irrigation treatments used application of both pathogen and biocontrol products at planting. The split-split-plot design used in this study provided a more accurate assessment of irrigation influences on Contans performance in controlling lettuce drop. Because a subsurface drip system is now more commonly employed in commercial lettuce production fields and the incidence of lettuce drop was shown to be comparatively lower in subsurface drip-irrigated lettuce fields than in furrow- or sprinklerirrigated fields (49), it will be an interesting and important extension of this work to study the effect of a subsurface drip system on the performance of Contans in suppressing lettuce drop.

In summary, crisphead and leaf lettuce were generally the lettuce types most susceptible to $S$. sclerotiorum, and sclerotia inoculum of $10 \mathrm{sclerotia} / \mathrm{m}^{2}$ of bed was sufficient to cause a significant increase in disease. Romaine lettuce was more tolerant, most likely a result of its architecture, and required up to $40 \mathrm{sclerotia} / \mathrm{m}^{2}$ of bed for significant increases in disease to become apparent. Irrigation method, at least regarding sprinkler versus furrow irrigation, does not significantly impact either $S$. sclerotiorum pathogenicity on lettuce or $C$. minitans parasitism of Sclerotinia spp. in lettuce production fields. Finally, this study further supports previous studies that the commercial product Contans containing $C$. minitans was highly effective for the control of lettuce drop caused by $S$. sclerotiorum in desert lettuce production systems, even at high sclerotial densities.

\section{ACKNOWLEDGMENTS}

This work was supported in part by the United States Department of Agriculture Cooperative State Research, Education and Extension Service grant 2004-34103-14902 and the University Of Arizona, College of Agriculture and Life Sciences.

\section{LITERATURE CITED}

1. Abawi, G. S., and Grogan, R. G. 1979. Epidemiology of diseases caused by Sclerotinia species. Phytopathology 69:899-904.

2. Adams, P. B., and Fravel, D. R. 1990. Economical biological control of Sclerotinia lettuce drops by Sporidesmium sclerotivorum. Phytopathology 80:1120-1124.

3. Bolton, M. D., Thomma, B. P. J., and Nelson, B. D. 2006. Sclerotinia sclerotiorum (Lib) de Bary: biology and molecular traits of a cosmopolitan pathogen. Mol. Plant Pathol. 7:1-16.

4. Bremer, E., Huang, H. C., Selinger, L. J., and Davis, J. S. 2000. Competence of Coniothyrium minitans in preventing infection of bean leaves by Sclerotinia sclerotiorum. Plant Pathol. Bull. 9:69-74.

5. Budge, S. P., and Whipps, J. M. 1991. Glasshouse trials of Coniothyrium minitans and Trichoderma species for the biological control of Sclerotinia sclerotiorum in celery and lettuce. Plant Pathol. 40:59-66.

6. Budge, S. P., and Whipps, J. M. 2001. Potential for integrated control of Sclerotinia sclerotiorum in glasshouse lettuce using Coniothyrium minitans and reduced fungicide application. Phytopathology 91:221-227.

7. California Agricultural Statistics Service. 1997. California Agricultural Statistics. California Department of Food and Agriculture.

8. Cassiolato, A. M. R., Baker, R., and Melo, I. S. D. 1997. Action of Trichoderma harzianum mutants on the formation and carpogenic germination of Sclerotinia sclerotiorum sclerotia and lettuce plant survival. Fitopatol. Bras. 22:34-38

9. Castro, B. L. 1995. Antagonism of some isolates of Trichoderma koningii, originating in Colombian soils, against Rosellinia bunodes, Sclerotinia sclerotiorum and Pythium ultimum. Fitopatol. Colomb. 19:7-18.

10. Chitrampalam, P., Figuli, P. J., Matheron, M. E., Subbarao, K. V., and Pryor, B. M. 2008. Biocontrol of lettuce drop caused by Sclerotinia sclerotiorum and $S$. minor in desert agroecosystems. Plant Dis. 92:1625-1634.

11. Chitrampalam, P., Figuli, P. J., and Pryor, B. M. 2006. Spatial pattern of sclerotia of Sclerotinia sclerotiorum in commercial lettuce fields in southern Arizona. (Abstr.) Phytopathology 96:S24.

12. Davet, P., and Martin, C. 1993. Resistance of Sclerotinia minor isolates to cyclic imides in lettuce field soils of Roussillon, France. J. Phytopathol. 138:331-342.

13. Dos Santos, A. F., and Dhingra O. D. 1982. Pathogenicity of Trichoderma spp. on the sclerotia of Sclerotinia sclerotiorum. Canadian J. Bot. 60:472-75.

14. Elad, Y. 2000. Trichoderma harzianum T39 preparation for biocontrol of plant diseasescontrol of Botrytis cinerea, Sclerotinia sclerotiorum, and Cladosporium fulvum. Biocontrol Sci. Technol. 10:499-507.

15. Fravel, D. R., Boland, G. J., and Kuykendall, L. D. 1997. Use of Sporidesmium scle- rotivorum for biocontrol of sclerotial plant pathogens. Pages 37-47 in: Plant Microbe Interaction and Biological Control. CRC Press, Boca Raton, FL.

16. Gerlagh, M., Goosen-van de Geijn, H. M., Fokkema, N. J., and Vereijken, P. F. G. 1999. Long-term biosanitation by application of $\mathrm{Co}$ niothyrium minitans on Sclerotinia sclerotiorum-infected crops. Phytopathology 89:141-147.

17. Gerlagh, M., Goossen-van de Geijn, H. M., Hoogland, A. E., and Vereijken, P. F. G. 2003. Quantitative aspects of infection of Sclerotinia sclerotiorum sclerotia by Coniothyrium minitans-timing of application, concentration and quality of conidial suspension of the mycoparasite. Eur. J. Plant Pathol. 109:489-502.

18. Grube, R., and Aburomia, R. 2004. Relationship between plant morphological traits and resistance to Sclerotinia minor in lettuce. HortScience 39:881.

19. Hao, J. J., and Subbarao, K. V. 2005. Comparative analyses of lettuce drop epidemics caused by Sclerotinia minor and S. scle rotiorum. Plant Dis. 89:717-725.

20. Hao, J. J., and Subbarao, K. V. 2006. Dynamics of lettuce drop incidence and Sclerotinia minor inoculum under varied crop rotations. Plant Dis. 90:269-278.

21. Hao, J. J., Subbarao, K. V., and Koike, S. T. 2003. Effects of broccoli rotation on lettuce drop caused by Sclerotinia minor and on the population density of sclerotia in soil. Plant Dis. 87:159-166.

22. Hayes, R. J., Wu, B. M., Pryor, B. M., Chitrampalam, P., and Subbarao, K. V. 2010. Assessment of resistance in lettuce (Lactuca sativa $\mathrm{L}$.) to mycelial and ascospore infection by Sclerotinia minor Jagger and S. sclerotiorum (Lib.) de Bary. HortScience 45:333341.

23. Hiremath, P. C., Kulkarni, S. A., Radder, G. D., Gidnavar, V. S., Chittapur, B. M., Itnal, C. J., Patil, B. N., and Babalad, H. B. 1998. Production of biocontrol agents for plant pathogens. Pages 291-293 in: Organics in Sustaining Soil Fertility and Productivity. G. D. Radder, V. S. Gidnavar, B. M. Chittapur, C. J. Itnal, B. N. Patil, and H. B. Babalad, eds. University of Agricultural Sciences, Dharwad, India.

24. Huang, H., Erickson, R. S., and Huang, C. 2000. Soil treatment with fungal agents for control of apothecia of Sclerotinia sclerotiorum in bean and pea crops. Plant Pathol. Bull. 9:53-58.

25. Huang, H. C., Bremer, E., Hynes, R. K., and Erickson, R. S. 2000. Foliar application of fungal biocontrol agents for the control of white mold of dry bean caused by Sclerotinia sclerotiorum. Biol. Control 18:270-276.

26. Hubbard, J. C., Subbarao, K. V., and Koike, S. T. 1997. Development and significance of Dicarboximide resistance in Sclerotinia minor isolates from commercial lettuce fields in California. Plant Dis. 81:148-153.

27. Inbar, J., Menendez, A., and Chet, I. 1996 Hyphal interaction between Trichoderma harzianum and Sclerotinia sclerotiorum and its role in biological control. Soil Biol. Biochem. 28:757-763.

28. Jones, D., and Watson, D. 1969. Parasitism and lysis by soil fungi of Sclerotinia sclerotiorum (Lib.) de Bary. a phytopathogenic fungus. Nature 224:287 288.

29. Jones, E. E., and Stewart, A. 2000. Selection of mycoparasite of sclerotia of Sclerotinia sclerotiorum isolated from New Zealand soils. $\mathrm{N}$. Z. J. Crop Hortic. Sci. 28:105-114.

30. Koch, E. 1999. Evaluation of commercial products for microbial control of soil-borne plant diseases. Crop Prot. 18:119-125.

31. Li, G. Q., Huang, H. C., and Acharya, S. N. 2002. Sensitivity of Ulocladium atrum, Coniothyrium minitans, and Sclerotinia sclerotiorum 
to benomyl and vinclozolin. Can. J. Bot. 80:892-898.

32. Li, G. Q., Wei, S. J., Jiang, D. H., and Huang, H. C. 2001. Control of Sclerotinia stem rot of canola by aerial application of Coniothyrium minitans. In: Proc. Sclerotinia 2001-XI Int. Sclerotinia Workshop. C. S. Young and K. J. D. Hughes, eds. Central Science Laboratory, York, UK

33. Lorito, M., Woo, S. L., Duffy, B., Rosenberger, U., and Defago, G. 1998. Advances in understanding the antifungal mechanisms of Trichoderma and new applications for biological control. Bull. OILB_SROP. 21:73-80.

34. Matheron, M. E., and Matejka, J. C. 1989. Evaluation of new fungicides for the control of leaf drop of lettuce. J. Rio Grande Valley Hortic. Soc. 42:71-74.

35. Matheron, M. E., and Porchas, M. 1996. New Fungicides Evaluated for Control of Sclerotinia Leaf Drop of Lettuce in 1997 and 1998. Vegetable Report. College of Agriculture and Life Sciences, The University of Arizona, Tucson.

36. Matheron, M. E., and Porchas, M. 2003. The University of Arizona Cooperative Extension Research Reports: Vegetable Crops, 19972003. College of Agriculture and Life Sciences, The University of Arizona, Tucson.

37. Matheron, M. E., and Porchas, M. 2004. Activity of boscalid, fenhexamid, fluazinam, fludioxonil, and vinclozolin on growth of Sclerotinia minor and S. sclerotiorum and development of lettuce drop. Plant Dis. 88:665668.
38. McLean, K. L., and Stewart, A. 2000. Application strategies for control of onion white rot by fungal antagonists. N. Z. J. Crop Hortic. Sci. 28:115-122.

39. McQuilken, M. P., Budge, S. P., and Whipps, J. M. 1997. Biological control of Sclerotinia sclerotiorum by film-coating Coniothyrium minitans on to sunflower seed and sclerotia. Plant Pathol. 46:919-929.

40. Melzer, M. G., and Boland, G. J. 1994. Epidemiology of lettuce drop caused by Sclerotinia minor. Can. J. Plant Pathol. 16:170176.

41. National Agricultural Statistics Service. 2002. U.S. Dep. Agric. U. S. Census of Agriculture. Online publication.

42. Nicholson, W. L., and Law, J. F. 1999. Method for the purification of bacterial endospores from soils: UV resistance of natural Sonoran desert soil population of Bacillus spp. with reference to $B$. subtilis strain 168 . J. Microbiol. Methods 35:13-21.

43. Phillips, A. J. L. 1986. Factors affecting the parasitic activity of Gliocladium virens on the sclerotia of Sclerotinia sclerotiorum and a note on its host range. J. Phytopathol. 116:212-220.

44. Prasad, R. D., and Rangeswaran, R. 1999. Granular formulation of Trichoderma and Gliocladium spp. in biocontrol of Rhizoctonia solani of chickpea. J. Mycol. Plant Pathol. 29:222-226.

45. Purdy, L. H. 1979. Sclerotinia sclerotiorum: history, diseases and symptomology, host range, geographic distribution and impact. Phytopathology 69:875-880.
46. Ryder, E. J. 1999. Lettuce, Endive and Chicory. CAB International, Wallingford, UK

47. Stoneman, W.F. 2002. Coniothyrium minitans for practical control of sclerotinia diseases. (Abstr.) Phytopathology 92:S105.

48. Subbarao, K. V. 1998. Progress toward integrated management of lettuce drop. Plant Dis. 82:1068-1078.

49. Subbarao, K. V., Hubbard, J. C., and Schulbach, K. F. 1997. Comparison of lettuce diseases and yield under subsurface and furrow irrigation. Phytopathology 87:877-883.

50. Whipps, J. M., and Budge, S. P, 1990. Screening for sclerotial mycoparasites of Sclerotinia sclerotiorum. Mycol. Res. 94:607-661.

51. Wu, B. M., Bhat, R.G., Kabir, Z., and Subbarao, K. V. 2003. Production of apothecia by Sclerotinia sclerotiorum in the Salinas valley. (Abstr.) Phytopathology 93:S131.

52. Wu, B. M., and Subbarao, K. V. 2002. Sclerotial survival of $S$. minor and $S$. sclerotiorum in California. (Abstr.) Phytopathology 92:S88.

53. Wu, B. M., and Subbarao, K. V. 2006. Analyses of lettuce drop incidence and population structure of Sclerotinia sclerotiorum and S. minor. Phytopathology 96:1322-1329.

54. Yates, I. E., Meredith, F., Smart, W., Bacon, C. W., and Jaworski, A. J. 1999. Trichoderma viride suppresses fumonisin $\mathrm{B} 1$ production by Fusarium moniliforme. J. Food Prot. 62:13261332.

55. Zazzerini, A., and Tosi, C. 1985. Antagonistic activity of fungi isolated from sclerotia of Sclerotinia sclerotiorum. Plant Pathol. 34:415421. 